\title{
MATERIAŁY WARSZTATOWE KS. PROF. STANISŁAWA WITKA W BIBLIOTECE ZAKŁADU TEOLOGII MORALNEJ KUL
}

\section{Wprowadzenie}

Ksiądz Stanisław Witek urodził się 24 grudnia 1924 r. w Mielcu, w woj. krakowskim (obecnie woj. rzeszowskie) ${ }^{1}$. W 1946 r. wstąpił do Seminarium Duchownego w Tarnowie, gdzie w 1951 r. otrzymał święcenia kapłańskie. Następnie odbył studia specjalistyczne na Sekcji Teologii Moralnej Wydziału Teologicznego KUL, uzyskując stopień doktora teologii na podstawie rozprawy: Przyjaźń w świetle nauki św. Tomasza z Akwinu. Po ukończeniu studiów specjalistycznych pełnił obowiązki rektora Niższego Seminarium Duchownego w Tarnowie, a potem pracował jako wykładowca teologii moralnej w Arcybiskupim Seminarium Duchownym we Wrocławiu. W 1962 r. został zatrudniony w Katolickim Uniwersytecie Lubelskim, początkowo na stanowisku adiunkta przy katedrze Teologii Moralnej Szczegółowej, a następnie kierownika tejże katedry. Pracownikiem naukowym KUL pozostał do końca swojego życia, zdobywając kolejne stopnie i stanowiska naukowe; w 1967 r. przeprowadzil przewód habilitacyjny na podstawie rozprawy: Natura pokory. Studium tomistyczne, a w 1975 r. otrzymal tytuł profesora nadzwyczajnego. W toku była także sprawa nadania tytułu profesora zwyczajnego, która jednakże z powodu jego śmierci nie została doprowadzona do końca. $Z$ okazji jubileuszu 60-lecia istnienia KUL został odznaczony Złotym Krzyżem Zasługi za nienaganną pracę pedagogiczną. Zmarł w Mielcu 6 stycznia 1987 r.

Ksiądz Profesor Stanisław Witek jest autorem wielu publikacji naukowych. Bibliografia jego prac obejmuje w sumie ponad 120 pozycji ${ }^{2}$. Do najbardziej

${ }^{1}$ Zob. F. Greniuk, Życie i działalność ks. prof. Stanistawa Witka, „Roczniki TeologicznoKanoniczne”, 36 (1989) z. 3, s. 5-17; t e nż e, Sp. ks. prof. Stanistaw Witek (1924-1987), „Collectanea Theologica”, 57 (1987) z. 4, s. 68-71; W. M. W i t c k, W stużbie nauki, „Ateneum Kapłańskie", 82 (1990) t. 115, s. 72-77.

${ }^{2}$ Zob. F. Gre niuk, Bibliografia prac ks. prof. Stanistawa Witka, „Roczniki TeologicznoKanoniczne", 36 (1989) z. 3, s. 19-29. 
znanych należą: Chrześcijańska wizja moralności $i^{3}$, Teologia życia duchowego ${ }^{4}$, Sakrament Pojednania, ${ }^{5}$ Duszpasterstwo $w$ konfesjonale ${ }^{6}$.

Spuścizna naukowa ks. Stanisława Witka nie została jeszcze opracowana. Obok prac drukowanych należy do niej również bardzo duży zbiór materiałów warsztatowych, które wkrótce po jego śmierci (w styczniu 1987 r.) zostały przeniesione do Biblioteki Zakładu Teologii Moralnej KUL (sala nr 140), gdzie znajdują się do chwili obecnej. Materiały rozdzielone przez ks. Witka do tek i kartotek są aktualnie częściowo przemieszane, także ich ułożenie na regałach jest zupełnie przypadkowe. Spora ilość materiałów (ok. 400 tek i 14 kartotek) pozwala domyślać się, że w mieszkaniu Profesora musiały być one $w$ jakiś sposób uporządkowane i posegregowane. Obecnie trudno jest odtworzyć ten układ, a nawet dokonać szczegółowej ich klasyfikacji.

$\mathrm{Na}$ zawartość tek składają się notatki, wypisy, fragmenty książzek i czasopism. Notatki i wypisy sporządzone zostały $\mathrm{z}$ reguły ręcznie, starannie $\mathrm{i}$ czytelnie, także w obcych językach (głównie w angielskim, francuskim, niemieckim i łacińskim), najczęściej na papierze maszynowym. W kilku tekach znajdują się projekty i szkice planowanych opracowań. Mają one charakter robroczy, tzn. obok zagadnień problemowych zawierają również informacje o przeznaczeniu i charakterze opracowania, a nawet przewidywaną ilość stron np. „Traktat o śmierci, podręcznik o charakterze powszechnego przeznaczenia (księża i świeccy), styl popularyzatorski, ale nie dewocyjny, wielkość 400 stron maszynopisu"7. Zachowało się także kilka artykułów w maszynopisie ${ }^{8}$.

Część zbioru materiałów stanowią fragmenty książek i czasopism. Książki - przede wszystkim o charakterze podręcznikowym - są podzielone na części i umieszczone w odpowiedniej tece lub kartotece. Do danego fragmentu dołączona jest karta tytułowa, czasem spis treści, ewentualnie informacja o pochodzeniu np: „Sawicki, Paragrafy i żywi ludzie”. W przypadku niektórych pozycji obcojęzycznych podane są dodatkowe informacje na temat treści np. „sakrament kapłaństwa - kierownictwo duchowe". Jednakże zachowało się sporo fragmentów książek bez adnotacji o autorze i tytule.

Obok notatek i wypisów teki zawierają także wycinki z książek i czasopism naklejone na kartki o formacie A4. Charakterystyczne dla tej metody pracy jest to, że wycinki zaopatrzone są w zapis cyfrowy [np: (867) 27-29] ${ }^{9}$ w miejsce

${ }^{3}$ Poznań 1983.

${ }^{4}$ Lublin 1986.

${ }^{5}$ Podręcznik dla duszpasterzy, Poznań 1979.

${ }^{6}$ Poznań 1988.

${ }^{7}$ Teka Ars moriendi, Biblioteka Zakładu Teologii Moralnej KUL, Lublin.

${ }^{8}$ Są to artykuły już opublikowane poza jednym: Zagadnienie sensu życia $w$ wielkich religiach świata.

${ }^{9}$ Cyfra 867 oznacza numer pozycji w spisie, natomiast dalsze cyfry dotyczą stron. W tym 
danych bibliograficznych. Kod ten odsyła do teki zawierającej sporządzony ręcznie, ponumerowany spis książek z podaniem autora, tytułu i tomu. Spis ten obejmuje blisko 2 tysiące woluminów ${ }^{10}$ polskich i obcojęzycznych o różnorodnej tematyce. Stanowi on niejako klucz do materiałów ks. Witka, ponieważ umożliwia ich zidentyfikowanie. Dla badacza zaś może być cenną informacją na temat warsztatu naukowego Księdza Profesora.

Teki mają charakter problemowy i są zróżnicowane objętościowo. Prawie wszystkie (poza kilkoma) są zatytułowane. Wiele $z$ nich posiada wewnętrzny podzial $^{11}$. Tytuły tek i przejrzenie ich zawartości posłużyły za podstawę prezentowanej tu klasyfikacji. Pod względem rzeczowym można je podzielić na cztery zasadnicze grupy.

Grupę pierwszą i równocześnie najliczniejszą tworzą materiały dotyczące historii Polski. Zostały one zgromadzone pod kątem planowanej monografii: Kultura moralna narodu polskiego ${ }^{12}$. Stanowią jedną z najciekawszych części spuścizny i zasługują na uwagę ze względu na bogatą zawartosć treściową. Z zachowanych notatek Profesora wynika, że główną treść książki stanowić miała moralność Polaków, przedstawiona na tle historii narodu i przemian europejskich. Cel ten miał być zrealizowany poprzez ukazanie stanu życia politycznego, społecznego i religijnego, co umożliwiłoby Autorowi wyodrębnienie cech narodowych przejawiających się w kulturze duchowej, a zwłaszcza w postawie wielkich postaci naszych dziejów (wzorach osobowych) ${ }^{13}$.

Do grupy drugiej zaliczono materiały dotyczące religii pozachrześcijańskich i kultury różnych narodów. Ksiądz Witek bowiem od początku swoich badań naukowych interesował się historią zjawisk moralnych, także w religiach poza-

przypadku chodzi o książkę E. D ąb rows k i e go, Religie Wschodu, Poznań 1962.

${ }^{10}$ Ilość podana jest w przybliżeniu, ponieważ spis uzupełniony jest dodatkami.

${ }^{11}$ Np. teka Wartości indywidualne: (egzystencjalne, somatyczne, psychiczne, duchowe, charakterologiczne, etyczne), podobnie teka Typologia: (1. typ stabilny, 2. typ labilny, 3. typ intrawertyczny, 4. typ ekstrawertyczny).

12 Tom 1 monografii liczy 1154 strony maszynopisu. Kopia tego tomu została przekazana do Biblioteki Seminarium Duchownego w Tarnowie.

13 „Historia Polski jest kanwą tej książki, ale faktycznie jej treść stanowi moralność Polaków. Pisana przez moralistę a nie zawodowego historyka podejmuje ona wątki pomijane zwykle przez fachowca, albo przedstawiane w sposób fragmentaryczny. Do nich przede wszystkim należy mentalność narodu, zwłaszcza w głównych jego przedstawicielach, władcach, rodach, wieszczach, działaczach. Mentalność ta wyraża się w psychice i twórczości; stąd w książce położono szczególny nacisk na psychologię wielkich postaci naszych dziejów oraz wypowiedzi o naszym usposobieniu narodowym, obejmujące najszersze rzesze Polaków. Aby nie traktować tych kolei naszego ducha w oderwaniu od tła ogólnej kultury europejskiej, którego on jest odroślą, jako punkt wyjścia w rozważaniu każdej epoki przedstawiono szeroki obraz tendencji zachodnich [...]. Analizę zasadniczą przeprowadzono w trzech aspektach: życia politycznego, spolecznego i religijnego, one bowiem wyznaczają główne płaszczyzny życia narodowego". Teka: Kultura moralna narodu polskiego, Biblioteka Zakładu Teologii Moralnej KUL, Lublin. 
chrześcijańskich i innych systemach etycznych. Świadczą o tym opublikowane artykuły na temat idei moralnych w starożytnym Egipcie, taoizmie i buddyzmie. Zgromadzone materiały z tej grupy ogólnie można podzielić na: dotyczące religii pierwotnych (Ameryka, Australia, Afryka), Bliskiego i Dalekiego Wschodu oraz kultury $\mathrm{z}$ kręgu narodów europejskich łącznie $\mathrm{z}$ ich prehistorią.

Grupę trzecią stanowią materiały o charakterze teologicznomoralnym. Dotyczą one m.in. sakramentów, wartości i typologii moralnej.

Ostatnią grupę tworzą teki, których zawartość dowodzi bogatych zainteresowań naukowych ks. Witka. Zgromadził w nich materiał z różnych dziedzin wiedzy (biologii, cybernetyki, ekonomii), który często wykorzystywał także w refleksji teologicznomoralnej ${ }^{14}$.

\section{Wykaz tek}

Z uwagi na różnorodność tematyczną materiałów warsztatowych ks. prof. Stanisława Witka przedstawiona tu klasyfikacja ma charakter bardzo ogólny. Jak już wspomniano, za jej podstawę posłużyły tytuły tek oraz przejrzenie ich zawartości. Zastosowany podział materiałów na cztery zasadnicze grupy znajduje potwierdzenie w zainteresowaniach Księdza Profesora, przejawiających się m.in. w jego publikacjach naukowych ${ }^{15}$. Dla przejrzystości klasyfikacji wprowadzone zostały dodatkowe podziały w ramach poszczególnych grup. Zachowano też oryginalną tytulaturę tek $z$ wyjątkiem koniecznych uzupeknień podanych w nawiasach kwadratowych. Dotyczy to przede wszystkim tek $\mathrm{z}$ grupy pierwszej tzw. biograficznych (wzory osobowe), gdzie zostały uzupełnione imiona, a przy innych wymienione niektóre nazwiska ${ }^{16}$.

\section{Materiały dotyczące kultury moralnej Polaków}

1. Tło historyczne

A. Okresy historyczne

Teki

- Sredniowiecze

- Średniowiecze

- XX-lecie

- Współczesność

\footnotetext{
14 Swiadczy o tym choćby artykul: Zastosowanie cybernetyki w teologii moralnej, „Summa* rium", 23 (1974) s. 271-275.

${ }^{15}$ Zob. Greniuk, Zycie, s. 10-1 1 .

${ }^{16}$ Spis nie uwzględnia kartotek. Dwie kartoteki zawierają bibliografię w układzie alfabetycznym, w jednej znajduje się spis czasopism. Materiał zgromadzony w pozostałych kartotekach dotyczy: zagadnień teologicznomoralnych (kapłaństwo, pokuta, cnoty społeczne), kultur (Chiny, Japonia, Indie) oraz różnych dziedzin wiedzy (psychologia, historia).
} 
B. Epoki i kierunki w dziejach kultury

- Odrodzenie

- Odrodzenie

- Barok

- Barok

- Rokoko

- Klasycyzm

- Sentymentalizm

- Oświecenie

- Oświecenie

- Oświecenie

- Preromantyzm

- Romantyzm

- Modernizm

- Neoromantyzm

- XX wiek. Literatura

C. Nurty filozoficzne i ideologie społeczne

- Pozytywizm

- Strukturalizm

- Marksizm

- Marksizm

- Socjalizm

D. Dzieje Polski

- Kultura moralna narodu polskiego [cz I - maszynopis]

- Piastowie

- Kontrreformacja

- Czasy saskie

- Konfederacja Barska

- Epoka rozbiorów

- Rozbiory

- Rozbiory. I

- Rozbiory. II

- Rozbiory. II

- Polska po rozbiorach

- 1789-1815 [Czasy Napoleona]

- Księstwo Warszawskie

- Królestwo Kongresowe

- Emigracja

- Gromady Ludu Polskiego

- Historia Polski. Lata 1860-1914 [maszynopis]

- II Rzeczpospolita

- Okupacja 
- Historia Polski po II wojnie

- 1944-1977 [Czasy współczesne]

- Polska Ludowa

2. Moralność życia politycznego

- Polityka

- Ustrój

- Sądy

- Prawo

- Bezprawie

- Bezprawie

- Bezprawie

- Przestępstwa

3. Moralność życia społecznego

A. Struktury podstawowe

- Małżeństwo. Rodzina. Historia

- Małżeństwo

- Rodzina

B. Warstwy i grupy społeczne

- Społeczność

- Królowie

- Magnaci

- Szlachta

- Służba

- Chłopi

- Dziady

- Inni

- Stosunki społeczne

C. Obyczajowość publiczna i kultura materialna

- Wzory życia

- Rozrywki

- Wierzenia

- Zabobony

- Czary

- Zle

- Pogrzeb

- Miasta

- Pieniądze

- Dom

- Jedzenie

- Zdrowie

- Moda

- Moda 
- Strój

- Luksus

D. Edukacja i związki młodzieżowe

- Szkoły

- Komisja Edukacji Narodowej

- Harcerstwo

E. Świadomość społeczna i prądy filozoficzne

- Literatura

- Narodowość

- Sarmatyzm

- Mesjanizm

- Warszawska Szkoła Historyczna

- Krakowska Szkoła Historyczna

- Polska filozofia narodowa

4. Moralność życia religijnego

A. Papieże, synody, duchowieństwo

- Papieże

- Jan Paweł II

- Synody. Biskupi

- [Homilie S. Wyszyńskiego]

- Księża

- Zakony

- Jezuici

B. Inne wyznania

- Prawosławie

- Arianie

- Protestanci

- Protestanci

- Protestantyzm niemiecki

5. Cechy narodowe

- Polska a Zachód

- Opinie obcych

- Religijność

- Katolicyzm

- Patriotyzm i etyka w twórczości literackiej

- Towarzyskość

- Grzeczność

- Surowość

- Okrucieństwo

- Pijaństwo

5. Wzory osobowe

- Abramowski [Edward] 
- Adamski [Józef]

- Asnyk [Adam)

- Bielski [Marcin]

- Birkowski [Fabian]

- Bobrzyński [Michał]

- Bogusławski [Wojciech]

- Bohomolec [Franciszek]

- Brodziński [Kazimierz)

- Brzozowski [Stanisław]

- Cieszkowski [Jan]

- Chlebowski [Bronisław]

- Chmielowski [Benedykt]

- Czajkowski [Michał]

- Czartoryscy

- Dawid [Władysław]

- Dembowski [Edward]

- Długosz [Jan]

- Dmochowski [Feliks]

- Dobrowolski [Stanisław]

- Drużbacka [Elżbieta]

- Dybowski [Benedykt]

- Dygasiński [Adolf]

- Dzieduszycki [Wojciech]

- Ehrenberg [Gustaw]

- Fredro [Aleksander]

- Fredro [Andrzej]

- Gołuchowski [Józef]

- Gombrowicz [Witold]

- Goszczyński [Seweryn]

- Górnicki [Łukasz]

- Hoene-Wroński [Józef]

- Hodi Tokarzewicz [Józef]

- Jaroński [Feliks]

- Jasiński [Jakub]

- Jezierski [Franciszek]

- Kalinka [Walerian]

- Kamieński [Henryk]

- Karpiński [Fanciszek]

- Kelles-Krauz [Stanisław]

- Klonowic [Sebastian]

- Kniaźnin [Franciszek]

- Kochanowski [Jan] 
- Kochowski [Wespazjan]

- Kołłątaj [Hugo]

- Konarski [Stanisław]

- Korzeniowski [Józef]

- Kotarbiński [Józef]

- Krasicki [Ignacy]

- Krasiński [Zygmunt]

- Kraszewski [Józef]

- Królikowski [Ludwik]

- Krzywicki [Tadeusz]

- Lelewel [Joachim]

- Lenartowicz [Teofil]

- Leszczyński [Stanisław]

- Libelt [Karol]

- Limanowski [Bolesław]

- Lubomirski [Stanisław]

- Lutosławski [Wincenty]

- Mahrburg [Adam]

- Majmon [Salomon]

- Mickiewicz [Adam]

- Mochnacki [Maurycy]

- Modrzewski [Andrzej]

- Morsztyn [Zbigniew]

- Naruszewicz [Adam]

- Niemcewicz [Julian]

- Norwid [Cyprian]

- Ochorowicz [Julian]

- Opalińscy

- Orkan [Władysław]

- Orzechowski [Stanisław]

- Orzeszkowa [Eliza]

- Pasek [Jan]

- Pawlicki [Stefan]

- Pietrażycki [Henryk]

- Potocki [Wacław]

- Prus [Bolesław]

- Rej [Mikołaj]

- Rzewuski [Wacław]

- Sęp-Szarzyński [Mikołaj]

- Sienkiewicz [Henryk]

- Skarga [Piotr]

- Słowacki [Juliusz] 
- Starowolski [Szymon]

- Staszic [Stanisław]

- Straszewski [Maurycy]

- Struve [Henryk]

- Suchodolscy

- Supiński [Józef]

- Szaniawski [Jerzy]

- Szczepanowski [Stanisław]

- Szujski [Józef]

- Szymonowic [Szymon]

- Śniadecki [Jędrzej]

- Swiętochowski [Aleksander]

- Towiański [Andrzej]

- Trembecki [Stanisław]

- Trentowski [Bronisław]

- Twardowski [Samuel i Kazimierz]

- Wartenberg [Mścisław]

- Weyssehoff [Józef]

- Węgierski [Tomasz]

- Wiszniewski [Michał]

- Witkiewicz [Stanisław]

- Worcell [Stanisław]

- Wyspiański [Stanisław]

- Zabłocki [Franciszek]

- Zapolska [Gabriela]

- Zdziechowski [Marian]

- Zimorowic [Szymon]

- A [Ancuta, Anczyc]

- B [Biernacki, Bronikowski]

- C [Ciołek, Czahrowski]

- D [Darasz, Dąbrowska]

- E [Estkowski]

- F [Feliński, Frowin]

- G [Godebski, Grzegorz z Sanoka]

- H [Hempel, Hussowski]

- I [Iłłakowiczówna, Iwaszkiewicz]

- J [Jarzębski, Jurkowski]

- K [Komeński, Kremer]

- L [Lange, Lemański]

- Ł [Łoziński, Łyszczyński]

- M [Miarka, Mniszkówna]

- N [Nalepiński, Nowaczyński] 
- O [Ordon, Odyniec]

- P [Podhorski, Pudłowski]

- R [Radziwiłł, Rapacki]

- S [Siemek, Szczuka]

- T [Tarnowski, Traugutt]

- U [Ujeski, Urbanowska]

- W [Wolska, Woronicz]

- Z [Załuski, Zawiejski]

- $\dot{Z}$ [Żabczyc, Żochowski]

\section{Materiały z zakresu historii idei moralnych}

1. Kultury pierwotne

- Religie pierwotne

- Azja Południowo-Wschodnia

- Syberia

- Azja Centralna [Środkowo-Północna]

- Arktyka. Eskimosi

- Afryka

- Afryka

- Ameryka

- Ameryka Poludniowa

2. Bliski Wschód i Afryka

- Bliski Wschód

- Mezopotamia

- Hetyci

- Izrael

- Persja

- Iran. Literackie prądy

- Chrześcijaństwo w starożytności

- Etiopia

- Etiopia

- Islam

- Islam. Literatura

3. Daleki Wschód

- Chiny

- Chiny

- Chiny

- Chiny. Historia literatury

- Chiny. Konfucjanizm. Buddyzm

- Japonia. Literatura

- Mongolia

- Indie 
- Buddyzm

- Dżinizm

4. Europa

- Europa. Prehistoria

- Europa. Prehistoria

- Europa Południowo-Wschodnia

- Anglia

- Czechy

- Francja

- Francja

- Hiszpania. Portugalia

- Luksemburg

- Niemcy

- Skandynawia

- Skandynawia i kraje nadbałtyckie

- Włochy

- Celtowie

- Etruskowie

- Germanowie

- Scytowie

III. Materialy o charakterze telogiczno-moralnym

1. Sakramenty

A. Sakrament Małżeństwa

- Małżeństwo

- Małżeństwo

- Rodzina

B. Sakrament Kapłaństwa

- Kapłaństwo

- Kapłaństwo

C. Sakrament Pokuty

- Duszpasterstwo w konfesjonale [fragment maszynopisu]

- Sakrament Pojednania

- Kierownictwo duchowe

- Grzechy

- Grzechy

- Zbiorowe [grzechy]

- Spowiedź

- Spowiedź

2. Aksjologia

- Wartości

- Wartości 
- Miłość

- Życie

- Życie i jego wartości

- Wartości indywidualne

- Indywidualne [wartości]

- Wartości duchowe

- Dobra witalne

- Egzystencjalne

- Eklezjalne

- Ekologiczne

- Ekonomiczne

- Ekonomiczne

- Ergologiczne

- Kosmologiczne

- Kulturowe

- Religijne

- Somatyczne

- Somatyczne

- Strukturalne

- Srodowiskowe

- Technologiczne

- Witalne

- Witalne

- Sfera indyw. ludzk. [indywidualności ludzkiej]

- Sfera kult. środow. [kultury środowiskowej]

- Sfera twórczości ludzkiej

- Styl życia

3. Typologia

- Typologia

- Typologia

- Wykiad specjalny T[eologii] M[oralnej] [typologia]

4. Etyka seksualna

- Etyka seksualna

- Erotyka

- Dewiacje seksualne

- Aborcja

- Antykoncepcja

5. Inne

- Teologia moralna. Problematyka i układ podręcznika. (Projekt dyskusyjny.) Lublin 1968. (Na prawach rękopisu)

- Układ T[eologii] M[oralnej]

- Hasła moralne A- $\dot{Z}$ 
- Zagadnienia moralne

- Zagadnienia moralne

- Teologia moralna szczegółowa

- [Publikacje ks. J. Pryszmonta]

- Filozofia moralna

- Teilhard

- Principia

- Perfekcjonizm

- Człowiek

- Droga życia

- Droga życia

- Potrzeby

- Potrzeby człowieka

- Wychowanie

- Komunikacja międzyosobowa

- Język

- Ars moriendi

- Praca

- Rekreacja

- Narkomania

- Recydywiści

IV. Materiały dotyczące różnych dziedzin i zagadnień

- Polityka

- Polityka

- Zagadnienia polityczne

- Ekonomia

- Miasto

- Kultura

- Estetyka

- Etyka

- Psychologia religii

- Psychologia religii

- Kosmologia

- Oceany

- Biologia

- Ekologia

- Ekologia

- Technika

- Cybernetyka

- Metodologia

- Metoda pracy 